Article

\title{
Effect of Feeding System on Enteric Methane Emissions from Individual Dairy Cows on Commercial Farms
}

\author{
Max Eckert, Matt Bell * (D), Sarah Potterton, Jim Craigon, Neil Saunders, Ruth Wilcox, \\ Morag Hunter, Jennifer Goodman and Phil Garnsworthy iif
}

School of Biosciences, Sutton Bonington Campus, The University of Nottingham, Loughborough LE12 5RD, UK; max.j.eckert@gmail.com(M.E.); sarah.potterton@nottingham.ac.uk (S.P.); jim.craigon@nottingham.ac.uk (J.C.); neil.saunders@nottingham.ac.uk (N.S.); ruth.wilcox@me.com (R.W.); m.hunter@nottingham.ac.uk (M.H.); jennifer.goodman@nottingham.ac.uk (J.G.); phil.garnsworthy@nottingham.ac.uk (P.G.)

* Correspondence: matt.bell@nottingham.ac.uk; Tel.: +44-115-951-6056

Received: 17 January 2018; Accepted: 21 February 2018; Published: 24 February 2018

\begin{abstract}
This study investigated the effects of feeding system on diurnal enteric methane $\left(\mathrm{CH}_{4}\right)$ emissions from individual cows on commercial farms. Data were obtained from 830 cows across 12 farms, and data collated included production records, $\mathrm{CH}_{4}$ measurements (in the breath of cows using $\mathrm{CH}_{4}$ analysers at robotic milking stations for at least seven days) and diet composition. Cows received either a partial mixed ration (PMR) or a PMR with grazing. A linear mixed model was used to describe variation in $\mathrm{CH}_{4}$ emissions per individual cow and assess the effect of feeding system. Methane emissions followed a consistent diurnal pattern across both feeding systems, with emissions lowest between 05:00 and 08:59, and with a peak concentration between 17:00 and 20:59. No overall difference in emissions was found between feeding systems studied; however, differences were found in the diurnal pattern of $\mathrm{CH}_{4}$ emissions between feeding systems. The response in emissions to increasing dry matter intake was higher for cows fed PMR with grazing. This study showed that repeated spot measurements of $\mathrm{CH}_{4}$ emissions whilst cows are milked can be used to assess the effects of feeding system and potentially benchmark farms on level of emissions.
\end{abstract}

Keywords: cattle; greenhouse gas; measurements; diet; variation

\section{Introduction}

At the United Nations Climate Change Conference in 2015, a key component of the global agreement was to protect food production whilst also reducing greenhouse gas (GHG) emissions [1]. Dairy farming contributes $20 \%$ of total global GHG emissions from the livestock sector, with enteric $\mathrm{CH}_{4}$ being the largest source at $39 \%$ of dairy emissions [2]. Given the significance of $\mathrm{CH}_{4}$ as a GHG, reducing enteric $\mathrm{CH}_{4}$ emissions from dairy cows whilst maintaining levels of milk production could prove an important strategy for countries to meet reduction targets in global emissions. Enteric $\mathrm{CH}_{4}$ is produced in the digestive tract by Archaea microorganisms as a by-product of anaerobic fermentation (methanogenesis). This process results in 3\% to $14 \%$ loss in gross energy intake, which is largely dependent on composition of the animals' diet and level of feed intake [3].

Until recently, most of the methods used to quantify $\mathrm{CH}_{4}$ emissions from cattle involved housing animals in respiration chambers [4-6]. Respiration chamber measurements are often costly, fixed in location so not suitable for commercial farm use, and potentially inhibit animal behaviour that would be expressed in the animals' normal environment. An alternative approach for measuring emissions from grazing animals is the sulphur hexafluoride $\left(\mathrm{SF}_{6}\right)$ technique $[7,8]$, where a small permeation tube containing the tracer gas is placed in the rumen of the animal. However, as with 
chambers, the $\mathrm{SF}_{6}$ technique is not suited to sampling a large population of animals on commercial farms due to restrictions on use of gas and the attachment of equipment to animals. Recent research has focused on collecting data from commercial herds through non-invasive approaches that take repeated spot measurements whilst cattle are feeding [6,9], being milked [10-12], or standing [13]. Frequent sampling of gas emissions has been found to provide repeatable measurements that allow assessment of within-cow, between-cow, diet and temporal effects on $\mathrm{CH}_{4}$ emissions. Estimates of $\mathrm{CH}_{4}$ made during milking have been found [10] to be correlated with total daily $\mathrm{CH}_{4}$ emissions by the same cows when housed subsequently in respiration chambers. Also, the technique of repeated spot measurements can identify known high and low $\mathrm{CH}_{4}$-producing diets [10], demonstrating that the methodology was sensitive enough to assess differences in diet treatments. Crompton et al. [14] identified the relationship between the time of feeding and $\mathrm{CH}_{4}$ emissions, with a rapid increase in emissions after an animal consumes food followed by a gradual decline. Several studies have observed a diurnal pattern to $\mathrm{CH}_{4}$ emissions from ruminant livestock $[9,14,15]$, which is affected by feed allowance and feeding frequency [14], with no overall influence on average daily $\mathrm{CH}_{4}$ yield [16,17].

The current study builds on the research of Bell et al. [18], who found considerable unexplained variation in $\mathrm{CH}_{4}$ emissions among farms that warranted further investigation with the addition of diet composition and feed intake data, which are known to explain a large proportion of variation in emissions [19].

The objective of the current study was to assess the effect of feeding system (PMR vs. PMR with grazing) on diurnal enteric $\mathrm{CH}_{4}$ emissions from dairy cows on commercial farms.

\section{Materials and Methods}

\subsection{Data}

Data were obtained from 21,324 individual milkings of 830 cows across 12 commercial farms in the UK. Each farm was visited once during the years 2011 to 2013, with production data and $\mathrm{CH}_{4}$ measurements collected for at least seven days. Farms were visited during different seasons to allow grazing and non-grazing systems to be monitored. Cows in this study were milked individually at automatic (robotic) milking stations which recorded cow ID, time of milking, duration of milking, stage of lactation, lactation number, milk yield, robot concentrate intake, and live weight at each milking for each individual cow (Table 1). 
Table 1. Mean herd size, number of milking stations, feeding system category (Partial mixed ration (PMR) or PMR with grazing), month of year for sampling, and mean (s.d.) lactation number, days in milk, milk yield, live weight, dry matter intake and methane emissions per cow for each herd.

\begin{tabular}{|c|c|c|c|c|c|c|c|c|c|c|}
\hline Farm No. & $\begin{array}{l}\text { Number } \\
\text { of Cows }\end{array}$ & $\begin{array}{c}\text { Number of } \\
\text { Milking Stations }\end{array}$ & $\begin{array}{l}\text { Feeding } \\
\text { System }\end{array}$ & $\begin{array}{l}\text { Month of } \\
\text { Sampling }\end{array}$ & $\begin{array}{l}\text { Lactation } \\
\text { No. }\end{array}$ & $\begin{array}{l}\text { Days } \\
\text { in Milk }\end{array}$ & $\begin{array}{l}\text { Milk } \\
\text { Yield }\end{array}$ & $\begin{array}{c}\text { Live } \\
\text { Weight }\end{array}$ & $\begin{array}{c}\text { Dry } \\
\text { Matter Intake }\end{array}$ & $\begin{array}{l}\text { Methane } \\
\text { Emissions }\end{array}$ \\
\hline & & & & & & & $\mathrm{kg} /$ day & kg & $\mathrm{kg} /$ day & $\mathrm{mg} / \mathrm{L}$ \\
\hline A & 65 & 1 & PMR + Grazing & 10 & $4.1(2.4)$ & $79(51)$ & $24.3(8.6)$ & $586(74)$ & $16.9(2.5)$ & $1.9(1.2)$ \\
\hline B & 53 & 1 & PMR + Grazing & 9 & $3.2(1.9)$ & $173(92)$ & $28.2(10.0)$ & $622(31)$ & $18.3(1.4)$ & $2.6(1.5)$ \\
\hline $\mathrm{C}$ & 51 & 1 & PMR + Grazing & 4 & $3.6(1.8)$ & $168(99)$ & $28.5(10.3)$ & $642(60)$ & $18.9(1.8)$ & $3.5(2.5)$ \\
\hline $\mathrm{D}$ & 47 & 1 & PMR + Grazing & 4 & $2.3(1.2)$ & $161(113)$ & $27.7(11.2)$ & $611(59)$ & $18.1(1.9)$ & $2.5(1.7)$ \\
\hline $\mathrm{E}$ & 66 & 1 & PMR + Grazing & 5 & $4.0(3.3)$ & $130(86)$ & $28.8(9.4)$ & $625(57)$ & $18.5(1.8)$ & $3.7(3.2)$ \\
\hline $\mathrm{F}$ & 45 & 1 & PMR + Grazing & 6 & $3.5(2.3)$ & $135(80)$ & $27.0(9.2)$ & $598(72)$ & $17.7(2.3)$ & $4.0(2.2)$ \\
\hline G & 116 & 2 & PMR & 6 & $2.6(1.6)$ & $159(90)$ & $26.1(8.8)$ & $625(73)$ & $18.2(2.1)$ & $4.0(2.6)$ \\
\hline $\mathrm{H}$ & 96 & 2 & PMR & 8 & $2.9(2.0)$ & $163(102)$ & $27.1(9.9)$ & $593(75)$ & $17.5(2.2)$ & $3.9(2.2)$ \\
\hline I & 46 & 1 & PMR & 11 & $1.0(0.0)$ & $99(31)$ & $25.2(5.4)$ & $547(44)$ & $16.2(1.3)$ & $0.6(0.5)$ \\
\hline $\mathrm{J}$ & 55 & 2 & PMR & 11 & $3.7(1.8)$ & $136(111)$ & $28.9(10.9)$ & $690(63)$ & $20.1(2.0)$ & $2.4(1.1)$ \\
\hline $\mathrm{K}$ & 110 & 2 & PMR & 2 & $2.4(1.4)$ & $156(92)$ & $35.6(12.6)$ & $603(74)$ & $18.6(2.4)$ & $2.4(1.3)$ \\
\hline $\mathrm{L}$ & 80 & 2 & PMR & 2 & $2.8(1.8)$ & $158(87)$ & $19.1(8.3)$ & $578(71)$ & $16.4(1.9)$ & $3.7(3.1)$ \\
\hline Mean ${ }^{1}$ PMR + Grazing & & & & & $3.7(0.03)$ & $143(14.3)$ & $26.9(1.7)$ & $612(15.6)$ & $17.9(0.5)$ & \\
\hline Mean ${ }^{1}$ PMR & & & & & $2.6(0.04)$ & $145(13.9)$ & $26.5(1.6)$ & $607(15.4)$ & $17.8(0.5)$ & \\
\hline SED & & & & & 0.05 & 19.8 & 2.3 & 21.9 & 0.7 & \\
\hline P value & & & & & $<0.001$ & 0.912 & 0.854 & 0.809 & 0.835 & \\
\hline
\end{tabular}

${ }^{1}$ Predicted mean \pm s.e. presented for both feeding systems. Linear mixed model with unique cow ID within farm, milking station within farm and month of sampling added as random effects and covariates centred to a zero mean. SED means standard errors of differences. 
All cows were fed a partial mixed ration (PMR) containing forage and concentrates ad libitum, with additional concentrates fed whilst milking. Of the 12 farms studied, half the farms allowed the cows access to grass (PMR + grazing) during the day. Dry matter intake of individual cows was predicted from their milk yield and live weight using the equation by MAFF [20] as: Dry matter intake $(\mathrm{kg} /$ day $)=0.025 \times$ live weight $(\mathrm{kg})+0.1 \times$ milk yield $(\mathrm{kg} /$ day) . Records on the composition of diet and forage (Table 2) and concentrate feeds (Table 3) were obtained from each farm, with feed samples analysed by a commercial analytical laboratory (Sciantec Analytical Services, Cawood, UK). Cows used in this study were mainly Holstein-Friesian breed and remained on the same feeding regime throughout the measurement period.

Table 2. Forage percentage (grass percentage in the diet and in parentheses) in the diet and forage nutrient content for each farm.

\begin{tabular}{cccccccc}
\hline Farm & Forage & $\begin{array}{c}\text { Dry } \\
\text { Matter (DM) }\end{array}$ & Starch & $\begin{array}{c}\text { Neutral } \\
\text { Detergent Fibre }\end{array}$ & $\begin{array}{c}\text { Crude } \\
\text { Protein }\end{array}$ & Oil & $\begin{array}{c}\text { Metabolisable } \\
\text { Energy }\end{array}$ \\
\hline & \% & $\mathbf{g} / \mathbf{k g}$ & $\mathbf{g} / \mathbf{k g}$ DM & $\mathbf{g} / \mathbf{k g ~ D M}$ & $\mathbf{g} / \mathbf{k g}$ DM & $\mathbf{g} / \mathbf{k g}$ DM & MJ/kg DM \\
\hline A & $68.7(4.5)$ & 316 & 133 & 424 & 132 & 40 & 10.2 \\
B & $68.4(58.8)$ & 172 & 0 & 362 & 237 & 31 & 11.0 \\
C & $48.5(3.8)$ & 398 & 6.1 & 291 & 74 & 22 & 11.2 \\
D & $57.9(1.3)$ & 344 & 186 & 452 & 109 & 26 & 11.2 \\
E & $62.6(1.4)$ & 494 & 74 & 507 & 143 & 51 & 10.7 \\
F & $75.6(46.7)$ & 304 & 0 & 426 & 153 & 26 & 11.1 \\
G & 60.2 & 263 & 156 & 333 & 79 & 18 & 10.0 \\
H & 45.8 & 351 & 6 & 470 & 132 & 32 & 10.6 \\
I & 57.1 & 570 & 0 & 592 & 104 & 18 & 9.8 \\
J & 49.4 & 313 & 124 & 414 & 128 & 29 & 11.2 \\
K & 58.3 & 394 & 56 & 474 & 116 & 18 & 11.0 \\
L & 68.0 & 283 & 45 & 440 & 124 & 48 & 10.3 \\
\hline
\end{tabular}

Table 3. Concentrate percentage in the diet and concentrate nutrient content for each farm.

\begin{tabular}{cccccccc}
\hline Farm & Concentrate & $\begin{array}{c}\text { Dry Matter } \\
\text { (DM) }\end{array}$ & Starch & $\begin{array}{c}\text { Neutral } \\
\text { Detergent Fibre }\end{array}$ & $\begin{array}{c}\text { Crude } \\
\text { Protein }\end{array}$ & Oil & $\begin{array}{c}\text { Metabolisable } \\
\text { Energy }\end{array}$ \\
\hline & \% & $\mathbf{g} / \mathbf{k g}$ & $\mathbf{g} / \mathbf{k g}$ DM & $\mathbf{g} / \mathbf{k g ~ D M}$ & $\mathbf{g} / \mathbf{k g}$ DM & $\mathbf{g} / \mathbf{k g}$ DM & $\mathbf{M J} / \mathbf{k g}$ DM \\
\hline A & 31.3 & 874 & 187 & 246 & 193 & 57 & 12.7 \\
B & 31.6 & 880 & 127 & 285 & 162 & 57 & 12.2 \\
C & 51.5 & 879 & 124 & 321 & 195 & 57 & 12.1 \\
D & 42.1 & 872 & 91 & 230 & 207 & 52 & 12.1 \\
E & 37.4 & 870 & 139 & 262 & 181 & 47 & 11.5 \\
F & 24.4 & 886 & 320 & 169 & 178 & 49 & 12.4 \\
G & 39.8 & 885 & 191 & 126 & 252 & 46 & 12.1 \\
H & 54.2 & 870 & 131 & 200 & 150 & 52 & 13.0 \\
I & 42.9 & 867 & 290 & 157 & 180 & 42 & 12.7 \\
J & 50.6 & 888 & 143 & 259 & 140 & 36 & 12.6 \\
K & 41.7 & 868 & 190 & 213 & 187 & 81 & 13.4 \\
L & 32.0 & 873 & 220 & 226 & 178 & 58 & 12.0 \\
\hline
\end{tabular}

\subsection{Measurements of Enteric $\mathrm{CH}_{4}$}

The $\mathrm{CH}_{4}$ concentration of eructed gas from cows was measured using the methodology devised by Garnsworthy et al. [10]. During milking, air was continually sampled from the feed bin in a robotic milking station at $1 \mathrm{~L}$ per minute through a polythene tube, whilst cows received concentrate feed dispensed in small amounts. Continual allocation of feed kept the cow's mouth and nose within the bin for the duration of milking. Concentration of $\mathrm{CH}_{4}$ in the breath of cows was measured using an infrared gas analyser (Guardian Plus; Edinburgh Instruments Ltd., Livingston, UK). Concentration of $\mathrm{CH}_{4}$ was logged at 1-s intervals on data loggers (Simex SRD-99; Simex Sp. Z o.o., Gdańsk, Poland) and visualised using logging software (Loggy Soft version 1.5.7.78; Simex Sp. Z o.o.). The $\mathrm{CH}_{4}$ analyser was calibrated using standard mixtures of $\mathrm{CH}_{4}$ in nitrogen $\left(0.0,0.25,0.50,0.75\right.$, and $1.0 \% \mathrm{CH}_{4}$, Thames 
Restek UK Ltd., Saunderton, UK). To enable $\mathrm{CH}_{4}$ concentrations to be adjusted to relative amounts released by the cow, the dilution factor was determined at the end of each sampling period at each robotic milking station and varied from 12.8 to 48.7 . To do this, a fixed volume (2.7 L) of $1.0 \% \mathrm{CH}_{4}$ in nitrogen was released at two locations in the feed bin of the milking station, which were at the base of the trough and at the centre of the feed bin level with the sample tube. Release of $\mathrm{CH}_{4}$ was replicated three times at each location, with the dilution factor being the mean ratio of six values of $\mathrm{CH}_{4}$ concentrations in released and sampled gas [18]. Concentration of $\mathrm{CH}_{4}$ in the air sampled followed a pattern of peaks and troughs demonstrating that a pulse release of $\mathrm{CH}_{4}$ was eructated by the cow. A custom-made program was then used to identify and quantify peaks in concentration when each cow visited the milking station (using cow ID and time of visit information), and extract the area and frequency of peaks. The peak frequency per minute was multiplied by the area under each peak to calculate the milligrams of $\mathrm{CH}_{4}$ per litre of air sampled. An eructation peak was defined as the time from the start of a rapid rise in concentration, until the following rise or return to baseline concentration. Milkings with less than three eructation peaks for $\mathrm{CH}_{4}$ concentration and peaks where the cow's head was not within the feed bin were excluded from the analysis. The $\mathrm{CH}_{4}$ emissions during each milking were calculated as: $\mathrm{CH}_{4}(\mathrm{mg} / \mathrm{L})=\left(\right.$ average integral of $\mathrm{CH}_{4}$ per peak $\times$ frequency of peaks) $\times$ dilution factor.

\subsection{Statistical Analysis}

Data were analysed using a linear mixed model in Genstat Version 18.1 (Lawes Agricultural Trust, 2012) to assess the effect of feeding system on log-transformed $\mathrm{CH}_{4}$ emissions (mg/L). Previous studies $[18,21]$ have identified important explanatory variables describing $\mathrm{CH}_{4}$ emissions per individual cow as being time of year, stage of lactation, time of day, and effect of farm. The following model was used to describe emissions from individual cows with the inclusion of explanatory variables for feeding system effects:

$$
\mathrm{Y}_{i j k l m n}=\mu+a \mathrm{DIM}+\mathrm{S}_{i}+b \mathrm{I}+c_{i} \mathrm{I} \times \mathrm{S}_{i}+\mathrm{H}_{j}+\mathrm{S}_{i} \times \mathrm{H}_{j}+\mathrm{F}_{l} \cdot \mathrm{A}_{k}+\mathrm{F}_{l}+\mathrm{F}_{l} \cdot \mathrm{R}_{m}+\mathrm{M}_{n}+\mathrm{E}_{i j k l m n}
$$

where $\mathrm{Y}_{i j k l m n}$ is the dependent variable of log-transformed $\mathrm{CH}_{4}$ emissions; $\mu$ is the overall mean; $a \mathrm{DIM}$ is the linear regression of $\mathrm{Y}$ on days in milk; $\mathrm{S}_{i}$ is the fixed effect of feeding system (PMR or $\mathrm{PMR}+$ grazing); $b \mathrm{I}$ and $c_{i} \mathrm{I}$ are the linear regressions of $\mathrm{Y}$ on estimated dry matter intake (kg/day); $\mathrm{H}_{j}$ is the fixed effect of time of day (categorised as six time periods of 01:00 to 04:59, 05:00 to 08:59, 09:00 to $12: 59,13: 00$ to $16.59,17: 00$ to 20.59 , and 21:00 to 00.59$) ; \mathrm{F}_{l} . \mathrm{A}_{k}$ is the random effect of individual cow within farm; $F_{1}$ is the random effect of farm (A to $\left.L\right) ; F_{1} \cdot R_{m}$ is the random effect of robot within farm; $\mathrm{M}_{\mathrm{n}}$ is the random effect of month of sampling; $\mathrm{E}_{i j k l m n}$ is the random error term. The terms $a, b$, and $c_{i}$ are regression coefficients.

The following diet components were also included in the analysis: forage intake, concentrate intake, starch, neutral detergent fibre (NDF), crude protein, oil (all percentage in diet), and metabolisable energy content (MJ/kg DM). Each component was added to Equation (1), but none was found to be significant $(P>0.05)$. Difference in lactation number, days in milk, milk yield, live weight, and estimated dry matter intake between feeding systems were obtained using Equation (1) with only the feeding system (PMR and PMR + grazing) included as the fixed effect.

\section{Results and Discussion}

Cows fed a PMR with grazing had a higher mean lactation number $(P<0.001)$ compared to cows fed a PMR (Table 1). There was no difference in number of days in milk, milk yield, live weight, or dry matter intake between cows fed a PMR or PMR with grazing. Therefore, any effects on $\mathrm{CH}_{4}$ emissions from cows could be assumed to be related to feeding system. Grandl et al. [5] found that $\mathrm{CH}_{4}$ emissions per unit intake changed in dairy cattle with age and was associated with changes in the efficiency of fibre digestibility with increasing age. The current study found no effect of lactation number on 
$\mathrm{CH}_{4}$ emissions, which is consistent with other studies [22]. As with others studies [19], the most important drivers of $\mathrm{CH}_{4}$ emissions were daily dry matter intake $(P<0.001)$ and variables related to changes in intake (i.e., days in milk and time of day, both $P<0.001$ ) (Table 4). The effect of diet, i.e., intake and composition, has been found to account for a large proportion of variation in enteric $\mathrm{CH}_{4}$ emissions from dairy cows [10,23]. Important components of a diet that influence methane emissions are known to be fermentable carbohydrate, fibre, fat, and digestible energy intake [19], but no effect of nutrient composition was found in the current study. Across feeding systems, increasing dry matter intake increased emissions by $0.02 \mathrm{mg} / \mathrm{L}$ per kilogram dry matter intake. The response in emissions to increased dry matter intake was higher for cows on a PMR with grazing at $0.03 \mathrm{mg} / \mathrm{L}$ per kilogram dry matter intake compared to a PMR system at $0.02 \mathrm{mg} / \mathrm{L}$ per kilogram dry matter intake $(P<0.001$; Table 4). Increasing forage content of diets is known to increase ruminal acetate production, which promotes $\mathrm{CH}_{4}$ production [3].

From the total of 21,324 milkings across all farms studied, 3106 were between 01:00 to 04:59, 3410 were between 05:00 to 08:59, 3490 were between 09:00 to 12:59, 3612 were between 13:00 to 16.59, 3893 were between 17:00 to 20.59, and 3813 were between 21:00 to 00.59 within a 24-h day. Therefore, the highest number of measurements were obtained between 17:00 to 20.59. A diurnal pattern was observed for $\mathrm{CH}_{4}$ emissions (Table 4), which is consistent with other studies [9,14,15]. Across feeding systems, emissions were lowest between 05:00 and 08:59, which would relate to a typical time to allocate feed to dairy cows, after which emissions increased to a peak concentration between 17:00 to 20.59. Differences in diurnal pattern were found between feeding systems ( $S E D=0.08, P<0.001$ ). Notably, between 21:00 and 00:59, emissions of cows on a PMR with grazing system remained high and similar to the previous time period, whereas emissions of cows on a PMR feeding system were reduced compared to the previous time period. The diurnal pattern is dependent on the time, frequency, and amount of food consumed [14], and has no overall influence on average daily $\mathrm{CH}_{4}$ emissions [16,17], which is consistent with the lack of an overall difference in emissions between feeding systems in the current study (log-transformed mean of $0.3 \mathrm{mg} / \mathrm{L}$ for PMR and $0.36 \mathrm{mg} / \mathrm{L}$ for PMR with grazing, $\mathrm{SED}=0.14, P>0.05$ ). The precise timing of feed allocation at each farm was not known, but would add to the interpretation of the results.

A number of studies have demonstrated techniques for obtaining measurements of $\mathrm{CH}_{4}$ emissions from individual cattle in their normal environment using repeated spot measurements $[9,11-13,15,18]$. The positive correlation between spot measurements of $\mathrm{CH}_{4}$ obtained during milking and total daily $\mathrm{CH}_{4}$ emissions by the same cows when housed subsequently in respiration chambers in a previous study [10], and the ability of the technique to detect the effect of diet [10,24], has led to considerable research into the spot measurement technique. The approach is reliant on several spot measurements within a day and over several days (at least seven days) of measurements to be able to rank cows as low or high producers of $\mathrm{CH}_{4}$ [25]. Further comparison of spot measurements on-farm and with the same cows in a respiration chamber are needed to validate or determine the limitations of the technique. The method used in the current study demonstrates the potential for benchmarking cattle or farms and selecting individual animals based on their emissions. 
Table 4. Results from multivariate analysis ${ }^{1}$ showing effect of partial mixed ration (PMR) or PMR with grazing feeding system on log-transformed $\mathrm{CH}_{4}$ emissions (mg/L) from dairy cows.

\begin{tabular}{|c|c|c|c|c|c|c|c|c|c|c|c|}
\hline Variable & & & Mean & s.e. $)^{2}$ & & & Effect (s.e.) & $\begin{array}{c}\text { Degrees } \\
\text { of Freedom }\end{array}$ & F Statistic & s.e.d. & $P$ Value \\
\hline Days in milk & & & & & & & $\begin{array}{c}0.0003 \\
(0.00007)\end{array}$ & 1 & 22.8 & & $<0.001$ \\
\hline Feeding system & PMR & PMR + grazing & & & & & & & & & \\
\hline & $0.30(0.1)$ & $0.36(0.1)$ & & & & & & 1 & 0.19 & 0.14 & 0.672 \\
\hline \multirow[t]{2}{*}{ Time of day } & $01: 00$ to $04: 59$ & $05: 00$ to $08: 59$ & $09: 00$ to $12: 59$ & $13: 00$ to 16.59 & $17: 00$ to 20.59 & $21: 00$ to 00.59 & & & & & \\
\hline & $0.31^{\mathrm{a}}(0.07)$ & $0.26^{\mathrm{b}}(0.07)$ & $0.33^{\mathrm{c}}(0.07)$ & $0.35^{\mathrm{d}}(0.07)$ & $0.37^{\mathrm{e}}(0.07)$ & $0.35^{\mathrm{d}}(0.07)$ & & 5 & 84.9 & 0.01 & $<0.001$ \\
\hline Feeding system $\times$ time of day & $01: 00$ to $04: 59$ & $05: 00$ to $08: 59$ & 09:00 to $12: 59$ & $13: 00$ to 16.59 & $17: 00$ to 20.59 & $21: 00$ to 00.59 & & & & & \\
\hline PMR & $0.28^{\mathrm{a}}(0.1)$ & $0.24^{\mathrm{b}}(0.1)$ & $0.31^{\mathrm{c}}(0.1)$ & $0.32^{c, d}(0.1)$ & $0.34^{\mathrm{d}}(0.1)$ & $0.30^{\mathrm{c}}(0.1)$ & & 5 & 4.3 & 0.08 & $<0.001$ \\
\hline PMR + grazing & $0.34^{a}(0.1)$ & $0.29^{\mathrm{b}}(0.1)$ & $0.35^{\mathrm{a}}(0.1)$ & $0.38^{\mathrm{c}}(0.1)$ & $0.40^{\mathrm{d}}(0.1)$ & $0.39^{c, d}(0.1)$ & & & & & \\
\hline $\begin{array}{c}\text { Predicted dry matter intake } \\
\text { Feeding system } \times \text { predicted } \\
\text { dry matter intake }\end{array}$ & & & & & & & $0.02(0.003)$ & 1 & 196.6 & & $<0.001$ \\
\hline PMR & & & & & & & $0.02(0.003)$ & 1 & 12.6 & & $<0.001$ \\
\hline PMR + grazing & & & & & & & $0.03(0.007)$ & & & & \\
\hline
\end{tabular}

${ }^{1}$ Linear mixed model with unique cow ID within farm, milking station within farm and month of sampling added as random effects and covariates centred to a zero mean. ${ }^{2}$ Means within a row with different superscript letters (i.e., a,b,c,d,e) differ significantly and attributed at $P<0.05$. SED means standard errors of differences. 


\section{Conclusions}

This is the first study to explore differences in $\mathrm{CH}_{4}$ emissions among commercial farm feeding systems (PMR vs. PMR with grazing and diet components). Similar overall mean levels of emissions were found for both feeding systems; however, differences were found in the diurnal pattern of $\mathrm{CH}_{4}$ emissions between feeding systems. The response in emissions to increasing dry matter intake was higher for cows fed PMR with grazing. Differences in emissions among farms were explained largely by factors associated with changes in individual feed intake over time. Measurement of $\mathrm{CH}_{4}$ emissions from cows during milking not only provides a method of comparing individual cows, but also benchmarking levels of emissions from different farming systems. Understanding this will aid the development of strategies that could contribute to reductions in emissions from the dairy sector whilst maintaining milk output.

Acknowledgments: This work was funded by Defra, the Scottish Government, Department of Agriculture and Rural Development (DARD) in Northern Ireland, and the Welsh Government as part of the UK's Agricultural GHG Research Platform project (www.ghgplatform.org.uk). We would like to thank all the farmers who allowed us to measure $\mathrm{CH}_{4}$ emissions on their farms and provided data for this study.

Author Contributions: Max Eckert analysed the data and wrote the paper; Matt Bell, Jim Craigon, and Phil Garnsworthy contributed to the analysis and writing of the paper; Sarah Potterton, Neil Saunders, Ruth Wilcox, and Morag Hunter collated the data.

Conflicts of Interest: The authors declare no conflict of interest.

\section{References}

1. UNFCCC. Available online: https://unfccc.int/files/essential_background/convention/application/pdf/ english_paris_agreement.pdf (accessed on 17 January 2018).

2. Gerber, P.J.; Steinfield, H.; Henderson, B.; Mottet, A.; Opio, C.; Dijkman, J.; Falcucci, A.; Tempio, G. Tackling Climate Change through Livestock-A Global Assessment of Emissions and Mitigation Opportunities; FAO: Rome, Italy, 2013, ISBN 925107920X.

3. Jouany, J.-P. Enteric methane production by ruminats and its control. In Gut Efficiency; The Key Ingredient in Ruminant Production; Andrieu, S., Wilde, D., Eds.; Wageningen Academic Publishers: Wageningen, The Netherlands, 2008; pp. 35-59. ISBN 9789086860678.

4. Blaxter, K.L.; Clapperton, J.L. Prediction of the amount of methane produced by ruminants. Br. J. Nutr. 1965, 19, 511-522. [CrossRef] [PubMed]

5. Grandl, F.; Amelchanka, S.L.; Furger, M.; Clauss, M.; Zeitz, J.O.; Kreuzer, M.; Schwarm, A. Biological implications of longevity in dairy cows: 2. Changes in methane emissions and efficiency with age. J. Dairy Sci. 2016, 99, 3472-3485. [CrossRef] [PubMed]

6. Hammond, K.J.; Jones, A.K.; Humphries, L.A.; Cromption, L.A.; Reynolds, C.K. Effects of diet forage source and neutral detergent fiber content on milk production of dairy cattle and methane emissions determined using GreenFeed and respiration chamber techniques. J. Dairy Sci. 2016, 99, 7904-7917. [CrossRef] [PubMed]

7. Granger, C.; Clarke, T.; McGinn, S.M.; Auldist, M.J.; Beauchemin, K.A.; Hannah, M.C.; Waghorn, G.C.; Clark, H.; Eckard, R.J. Methane emissions from dairy cows measured using the Sulfur Hexafluoride $\left(\mathrm{SF}_{6}\right)$ tracer and chamber techniques. J. Dairy Sci. 2007, 90, 2755-2766. [CrossRef] [PubMed]

8. Storm, I.; Hellwing, A.L.; Nielsen, N.; Madsen, J. Methods for Measuring and Estimating Methane Emission from Ruminants. Animals 2012, 2, 160-183. [CrossRef] [PubMed]

9. Manafiazar, G.; Zimmerman, S.; Basarab, J.A. Repeatability and variability of short-term spot measurement of methane and carbon dioxide emissions from beef cattle using GreenFeed emissions monitoring system. Can. J. Anim. Sci. 2017, 97, 118-126. [CrossRef]

10. Garnsworthy, P.C.; Craigon, J.; Hernandez-Medrano, J.H.; Saunders, N. On-farm methane measurements during milking correlate with total methane production by individual dairy cows. J. Dairy Sci. 2012, 95, 3166-3180. [CrossRef] [PubMed]

11. Lassen, J.; Lovendahl, P. Heritability estimates for enteric methane emissions from Holstein cattle measured using noninvasive methods. J. Dairy Sci. 2016, 99, 1959-1969. [CrossRef] [PubMed] 
12. Vanlierde, A.; Vanrobays, M.-L.; Gengler, N.; Dardenne, P.; Froidmont, E.; Soyeurt, H.; McParland, S.; Lewis, E.; Deighton, M.H.; Mathot, M.; et al. Milk mid-infrared spectra enable prediction of lactation-stage-dependent methane emissions of dairy cattle within routine population-scale milk recording schemes. Anim. Prod. Sci. 2016, 56, 258-264. [CrossRef]

13. Pickering, N.K.; Chagunda, M.G.G.; Banos, G.; Mrode, R.; McEwan, J.C.; Wall, E. Genetic parameters for predicted methane production and laser methane detector measurements. J. Anim. Sci. 2015, 93, 11-20. [CrossRef] [PubMed]

14. Crompton, L.; Mills, J.; Reynolds, C.; France, J. Fluctuations in methane emission in responce to feeding pattern in lactating dairy cows. In Modelling Nutrient Digestion and Utilisation in Farm Animals; Sauvant, D., Van Milgen, J., Faverdin, P., Friggens, N., Eds.; Wageningen Academic Publishers: Wageningen, The Netherlands, 2011; pp. 176-180. [CrossRef]

15. Kinsman, R.; Sauer, F.D.; Jackson, H.A.; Wolynetz, M.S. Methane and carbon dioxide emissions from dairy cows in full lactation monitored over a six-month period. J. Dairy Sci. 1995, 78, 2760-2766. [CrossRef]

16. Jonker, A.; Molano, G.; Antwi, C.; Waghorn, G. Feeding lucerne silage to beef cattle at three allowances and four feeding frequencies affects circadian patterns of methane emissions, but not emissions per unit of intake. Anim. Prod. Sci. 2014, 54, 1350-1353. [CrossRef]

17. Brask, M.; Weisbjerg, M.R.; Hellwing, A.L.F.; Bannink, A.; Lund, P. Methane production and diurnal variation measured in dairy cows and predicted from fermentation pattern and nutrient or carbon flow. Animal 2015, 9, 1795-1806. [CrossRef] [PubMed]

18. Bell, M.; Potterton, S.; Craigon, J.; Saunders, N.; Wilcox, R.; Hunter, M.; Goodman, J.; Garnsworthy, P. Variation in enteric methane emissions among cows on commercial dairy farms. Animal 2014, 8, 1540-1546. [CrossRef] [PubMed]

19. Bell, M.J.; Eckard, R.J. Reducing enteric methane losses from ruminant livestock-Its measurement, prediction and the influence of diet. In Livestock Production; Javed, K., Ed.; In Tech Publishing: Rijeka, Croatia, 2012; pp. 135-150. [CrossRef]

20. MAFF. Energy allowances and feeding systems for ruminants. In MAFF Reference Book 433; HMSO: London, UK, 1984, ISBN 0112426425.

21. Garnsworthy, P.C.; Craigon, J.; Hernandez-Medrano, J.H.; Saunders, N. Variation among individual dairy cows in methane measurements made on farm during milking. J. Dairy Sci. 2012, 95, 3181-3189. [CrossRef] [PubMed]

22. Ramírez-Restrepo, C.A.; Clark, H.; Muetzel, S. Methane emissions from young and mature dairy cattle. Anim. Prod. Sci. 2015, 56, 1897-1905. [CrossRef]

23. Mills, J.A.N.; Kebreab, E.; Yates, C.M.; Crompton, L.A.; Cammell, S.B.; Dhanoa, M.S.; Agnew, R.E.; France, J. Alternative approaches to predicting methane emissions from dairy cows. J. Anim. Sci. 2003, 81, 3141-3150. [CrossRef] [PubMed]

24. Bell, M.J.; Saunders, N.; Wilcox, R.; Homer, E.; Goodman, J.R.; Craigon, J.; Garnsworthy, P.C. Methane emissions among individual dairy cows during milking quantified by eructation peaks or ratio with carbon dioxide. J. Dairy Sci. 2014, 97, 6536-6546. [CrossRef] [PubMed]

25. Cottle, D.J.; Velazco, J.; Hegarty, R.S.; Mayer, D.G. Estimating daily methane production in individual cattle with irregular feed intake patterns from short-term methane emission measurements. Animal 2015, 9, 1949-1957. [CrossRef] [PubMed]

(c) 2018 by the authors. Licensee MDPI, Basel, Switzerland. This article is an open access article distributed under the terms and conditions of the Creative Commons Attribution (CC BY) license (http:/ / creativecommons.org/licenses/by/4.0/). 